\title{
International Strategic Alliance and Its Performance in China: The Resource-Based View
}

\author{
Yuhua $\mathrm{Li}^{1}$ \\ ${ }^{1}$ School of International Trade and Economics, Jiangxi University of Finance and Economics, Nanchang, China \\ Correspondence: Yuhua Li, the researcher of Jiahede-Jiangxi University of Finance and Economics Postdoctoral \\ Innovation Practical Base, Nanchang, 330013, China. E-mail: yuhuali28@gmail.com
}

Received: August 9, 2014

Accepted: September 30, 2014

Online Published: October 22, 2014

doi:10.5539/ijbm.v9n11p170

URL: http://dx.doi.org/10.5539/ijbm.v9n11p170

\begin{abstract}
This paper uses resource-based view to examine whether different resource complementary degree contributes to different international strategic alliance performance in China's banking sector. This paper uses strategic alliances established in China's banking sector from 2001 to 2008, and its alliance performance is from agreement date to December 31, 2010. Through Ordinary Least Squares regression and probit regression analyses, this paper found that resource complementary has positive but insignificant impact on alliance performance in China's banking sector. Two potential reasons could explain the results. First, the existence of liability of foreignness leads to the mismatch resources between Chinese banks and foreign banks. Second, the potential competition between foreign banks and Chinese banks hinder foreign banks to contribute their 100 percent resources. In addition, the case study on strategic alliance between China Minsheng Bank and Temasek also shows that high resource complementary doesn't contribute to high alliance performance.
\end{abstract}

Keywords: strategic alliance, Chinese banks, resource-based view, resource complementary

\section{Introduction}

To explain the strategic alliance and its alliance performance, a number of theories and models have been proposed, such as transaction cost theory (Hennart, 1998; Williamson, 1985); game theory (Parkhe, 1993); strategic behavior model (Das \& Teng, 1997). These theories, especially the dominant transaction cost economics, have proven to be useful in understanding the phenomenon of strategic alliances ${ }^{1}$. However, they do not assign a significant role to partner firm resources in theorizing about the strategic alliances (Das \&Teng, 2000a). Strategic alliances are essentially the result of resource integration among firms, and a resource-based view (RBV) has the potential for helping us understand alliances better.

The RBV has recently emerged as an alternative approach to understanding industrial organizations and their competitive strategies. A firm is equivalent to a broad set of valuable, rare, inimitable, and non-substitutability resources that it owns (Barney, 1991). It seems particularly appropriate for examining strategic alliances because firms essentially use alliances to gain access to other firms' valuable resources. Eisenhardt and Schoonhoven (1996) argue that strategic alliance is a serials cooperation relationship based on strategic resource needs and social resource opportunity. And Van (1976) thinks that the cooperation between firms is the movement of special resource in the organization. Because the RBV focuses on that the firms get the best output through the accumulation and exploitation of resources. And strategic alliances focus on the integration effect of different organization resources instead of the pure cooperation relationships. Therefore, RBV can be employed to examine the resource activities of strategic alliances.

In addition, strategic alliances could be treated as the alternative of the market mechanism to some extent and is the source of firms' competitive advantage (Barney, 1997). And thus the obtaining and accumulation of special resources become the strategic needs. However, because of efficiency variety of different market and different resource characteristics, the transactions of resources couldn't totally depend on the adjustment of market mechanism, the strategic alliances become one of the choices. From this point, RBV is the important analysis tool of strategic alliances. Therefore, we employ the RBV as the theoretical framework to analyze the relationship between strategic alliance and alliance performance.

Previous studies that have applied the resource-based view to strategic alliances cover only limited aspects, e.g. a 
systematically theoretical analysis (Das \& Teng, 2000a). However, few previous literatures conduct empirical studies on alliance performance from the resource-based view. The main objective of this paper is to examine the relationship between resource alignment and alliance performance to find out the impact of resource alignment on alliance performance. Many studies provide the theory explanation about the relationship about strategic alliance and alliance performance, but the empirical studies on it are very few. And this study will use the strategic alliances in China's banking sector to examine the issue.

Through OLS regression and probit regression analyses, this paper found that there is no significant difference on alliance performance between high-degree complementary strategic alliances and low-degree complementary strategic alliances, which suggest that the international strategic alliances in China's banking sector don't contribute to a good alliance performance. Two potential reasons could explain the results. First, the existence of liability of foreignness leads to the mismatch resources between Chinese banks and foreign banks. Second, the potential competition between foreign banks and Chinese banks hinder foreign banks to contribute their 100 percent resources. In addition, the case study on strategic alliances between China Minsheng Bank (CMB) and Temasek also show that resource complementary don't contribute to high alliance performance.

The reminder of this paper is as follows. Section 2 reviews the related literatures and then get the hypothesis. The variables and data are discussed in section 3. Section 4 gives the results and discussion. Section 5 concludes.

\section{Previous Studies and Hypothesis}

According to resource-based view, alliances create value when they pool resources from various parties and then pursue opportunities beyond a single firm's capabilities (Eisenhardt \& Schoonhoven, 1996). Thus, alliance performance depends on the alignment of specific resources between alliance partners (Chung, Singh, \& Lee, 2000); and an alliance will remain stable as long as the partners continue to have a desirable exchange of resources (Kogut, 1989).

Partner resource alignment refers broadly to the pattern, whereby the resources of partner firms are matched and integrated in an alliance (Das \& Teng, 2000a). This pattern defines the resource-based relationship between the partners. Previous researchers discuss resource alignment between partners (Beamish, 1987; Buckin \& Sengupta, 1993; Lei, 1993), the term "alignment" means a supplementary or complementary pattern-- that is, bringing in similar or dissimilar resources. Resource similarity in alliances is defined as the degree to which two partner firms contribute resources "comparable, in terms of both type and amount", to an alliance (Das \& Teng, 2000a). Resource similarity will be high if two partners contribute comparable amounts of similar types of resources to an alliance.

Several studies have illustrated the importance of complementarily in strategic alliances (Hamel, Doz, \& Prahalad, 1989; Hill \& Hellriegel, 1994; Olk, 1997; Teece, 1986). Hamel, Doz, and Prahalad (1989), for instance, suggest that mutual gain is possible if partners can complement each other's weakness since each partner in an alliance can access the complementary capabilities of their partners. More specifically, Teece (1986) argues that firms in high-growth industries need to form alliances with partners with complementary capabilities to ensure timely product introduction and to marshal a full array of capabilities. Olk (1997) hypothesizes a negative relationship between alliance performance and partner differences (i.e., complementary alignment) in terms of technology, research location, industry, etc. Because partners bring in something unique and non-redundant to the alliance, so that Hill \& Hellriegel (1994) hypothesize a positive relationship between a complementary resource alignment and alliance performance but found no empirical support either. Das \& Teng (2000a) hypothesize positive relationships in complementary because complementary have a positive effect on the collective strength and complementary resource not-significant related to inter-firm conflicts, however there is no empirical support either. Therefore, this paper proposes the hypothesis: the higher degree of resource complementary, the higher alliance performance they achieved.

\section{Variables, Data, and Methodology}

Alliance performance is one of the most studied topics in the alliance literature (Rothaermel \& Deeds, 2004) and (Steensma \& Corley, 2000). Alliances are evaluated using alliance longevity (Beamish, 1987) and profitability (Reuer \& Miller, 1997), goal achievement (Dollinger \& Golden, 1992; Thomas \& Trevino, 1993). Based the background of this strategic investment, this paper uses alliance longevity, equity change, divestment to measure the alliance performance. The longevity (Longevity) is the year at 2010 minus the agreement date of their strategic alliance. $P$ _increase is a dummy variable, if the foreign equity stake increases $P$ increase is 1 , otherwise is $0 . P \_$decrease is a dummy variable, if the foreign equity stake decreases $P \_$decrease is 1 , otherwise is 0 . 
Based on the resource similarity in terms of resource type and resource amount (Das \&Teng, 2000a), this paper define the degree of complementary. In China's banking sector, both Chinese banks and foreign financial institutions have the same type resources, such as know-how on corporate governance, risk management, credit card, but the amounts or quality of these resources are very different. Obviously, Chinese banks have little know-how on corporate governance, risk management. Therefore, this paper classifies the degree of complementary by classifying the number of cooperative items. If there are more than 3 cooperative items, the strategic alliance is classified as high-degree complementary alliance, otherwise low-degree complementary alliance. The degree of complementary ( $D_{-}$comp $)$is a dummy variable, if the strategic alliance is high-degree complementary alliance that has more than 3 cooperative items, $D \_$comp is 1 , otherwise is 0 . Most of the Chinese banks partner is state owned banks (SOCB), national joint-stock banks (JOCB), city commercial banks $(\mathrm{CCB})$, and rural commercial banks (RCB). This paper uses 3 dummy variables $(S O C B, J O C B$, and $C C B)$ to present the type of Chinese banks. LIST is a dummy variable, if the Chinese bank partner is a listed banks, LIST is 1 , otherwise is 0 .

Table 1. Variables description

\begin{tabular}{|c|c|c|}
\hline Variables & & Description \\
\hline \multirow{3}{*}{$\begin{array}{l}\text { Dependent } \\
\text { variables }\end{array}$} & Longevity & Longevity is the year at 2010 minus the agreement date of their strategic alliance. \\
\hline & P_increase & $\begin{array}{l}P_{-} \text {increase is a dummy variable, if the foreign equity stake increases } P_{-} \text {increase is } 1 \text {, } \\
\text { otherwise is } 0\end{array}$ \\
\hline & $P \_$decrease & $\begin{array}{l}P_{-} \text {decrease is a dummy variable, if the foreign equity stake decreases } P_{-} \text {decrease is } 1 \text {, } \\
\text { otherwise is } 0\end{array}$ \\
\hline $\begin{array}{l}\text { Independent } \\
\text { Variable }\end{array}$ & D_comp & $\begin{array}{l}\text { D_comp is a dummy variable, if the strategic alliance is high-degree complementary alliance } \\
\text { that has more than } 3 \text { cooperative items, } D \_ \text {comp is } 1 \text {, otherwise is } 0\end{array}$ \\
\hline \multirow{4}{*}{$\begin{array}{l}\text { Control } \\
\text { variables }\end{array}$} & $S O C B$ & $\begin{array}{l}S O C B \text { is a dummy variable, if the Chinese bank partner is state owned banks, SOCB is } 1 \text {, } \\
\text { otherwise is } 0\end{array}$ \\
\hline & $J O C B$ & $\begin{array}{l}J O C B \text { is a dummy variable, if the Chinese bank partner is national joint stock owned banks, } \\
\text { JOCB is } 1 \text {, otherwise is } 0\end{array}$ \\
\hline & $C C B$ & $\begin{array}{l}C C B \text { is a dummy variable, if the Chinese bank partner is city commercial banks, CCB is } 1 \text {, } \\
\text { otherwise is } 0\end{array}$ \\
\hline & LIST & $\begin{array}{l}\text { LIST is a dummy variable, if the Chinese bank partner is a listed banks, LIST is } 1 \text {, otherwise } \\
\text { is } 0\end{array}$ \\
\hline
\end{tabular}

In order to examine the relationship between resource alignment and alliance performance, this study first compares the alliance performance between low-degree complementary alliances and high-degree complementary alliances and try to find out whether there are differences between the two groups. And then this paper uses the following Model (1) - Model (3). Model (1) is constructed to examine the impact of resource complementary on the Longevity of alliances and Model (2) and Model (3) are constructed to examine the impact of resource complementary on $P_{-}$increase and $P_{-}$decrease of the strategic alliance. Finally, a case study is used to provide anecdotal evidence on the findings.

$$
\begin{aligned}
& \text { Longevity }_{i}=a_{i}+D_{-} \text {comp }_{i}+S O C B_{i}+J O C B_{i}+C C B_{i}+L I S T_{i}+e_{i} \\
& P_{\text {_ }} \text { increase }_{i}=a_{i}+D_{\text {_comp }}+\text { SOCB }_{i}+J O C B_{i}+C C B_{i}+L I S T_{i}+e_{i} \\
& P \_ \text {decrease }_{i}=a_{i}+D_{\text {_comp }}+\mathrm{SOCB}_{i}+\mathrm{JOCB}_{i}+C C B_{i}+\operatorname{LIST}_{i}+e_{i}
\end{aligned}
$$

This paper uses strategic alliances established in China's banking sector from 2001 to 2008, and its alliance performance is from agreement date to December 31,2010. The data mainly comes from Annual report of Chinese banks, two previous literatures (García-Herrero \& Santabárbara, 2008; Zhu et al., 2008), and public news. Table 2 lists the distribution information of Chinese banks. Chinese banks form the strategic alliances mainly after 2003 and concentrated on 2005 and 2006. And each type of Chinese banks is involved into the strategic alliances. 
Table 2. Distribution of foreign financial institutions and Chinese banks

Panel A: Time distribution of Chinese banks

\begin{tabular}{|c|c|c|}
\hline Year & Number & Chinese banks \\
\hline 2001 & 1 & Bank of Shanghai \\
\hline 2003 & 2 & Shanghai Pudong Development, China Industrial Bank \\
\hline 2004 & 4 & Bank of Communication, Shenzhen Development Bank, China Mingseng Bank, Qilu Bank \\
\hline 2005 & 10 & $\begin{array}{l}\text { Xian City Commercial Bank, Bank of Hangzhou, Huaxia Bank, Bank of Beijing, China Bohai Bank, Bank of } \\
\text { China, China Construction Bank, Bank of Tianjin, Nanchong Commercial Bank, Bank of Nanjing }\end{array}$ \\
\hline 2006 & 7 & $\begin{array}{l}\text { Industrial\&Commercial Bank of China, Shanghai Rural Commercial Bank, China CITIC Bank, Hangzhou } \\
\text { United Rural Cooperative Bank, Bank of Ningbo, Guangdong Development Bank, Bank of Chongqing }\end{array}$ \\
\hline 2007 & 1 & Bank of Qingdao \\
\hline 2008 & 1 & China Evergrowing Bank \\
\hline Total & 26 & \\
\hline
\end{tabular}

Panel B: Type distribution of Chinese banks

\begin{tabular}{|c|c|c|}
\hline Type & Number & Name of Chinese banks \\
\hline SOCB & 4 & $\begin{array}{l}\text { Bank of China, China Construction Bank, Industrial \& Commercial Bank of China (ICBC), Bank of } \\
\text { Communication }\end{array}$ \\
\hline JOCB & 9 & $\begin{array}{l}\text { Shenzhen Development Bank, China Minsheng Bank, Huaxia Bank, Shanghai Pudong Development Bank, } \\
\text { Guangdong Development Bank, China CITIC Bank, China Industrial Bank, China Bohai Bank, China } \\
\text { Evergrowing Bank }\end{array}$ \\
\hline $\mathrm{CCB}$ & 11 & $\begin{array}{l}\text { Bank of Nanjing, Bank of Chongqing, Bank of Tianjin, Bank of Ningbo, Bank of Beijing, Bank of Shanghai, } \\
\text { Bank of Hangzhou, Bank of Qindao, Xi'an City Commercial Bank, Qilu Bank, Nanchong Commercial Bank }\end{array}$ \\
\hline $\mathrm{RCB}$ & 2 & Shanghai Rural Commercial Bank, Hangzhou United Rural Cooperative Bank \\
\hline
\end{tabular}

Source: Compiled by authors according to the Zhu et al. (2008) and García-Herrero\&Santabárbara (2008), and some public information.

Note. 1) Because some Chinese banks have introduced different foreign banks at different year, this paper just collects the first time of Chinese banks introducing foreign strategic investment from foreign banks. 2) SOCB, state-owned commercial banks; JOCB, joint-stock commercial banks; $\mathrm{CCB}$, city commercial banks; $\mathrm{RCB}$, rural commercial banks.

\section{Results and Discussion}

Table 3 lists the descriptive statistics of the dependent variables and independent variables. The mean value of Longevity is 5.000 which indicate that the longevity of most strategic alliances is 5 years. $19.4 \%$ of the foreign strategic alliance partner increases their stakes in Chinese banks and $30.6 \%$ of the foreign strategic alliance partner decreases their stakes in Chinese banks. The average value of D_comp is 0.667 , which indicates that there are more foreign banks involved in high-degree complementary strategic alliances than low-degree complementary strategic alliance.

Table 3. Descriptive statistics

\begin{tabular}{llllll}
\hline Variable & Obs & Mean & Std. Dev. & Min & Max \\
\hline Longevity & 36 & 5.000 & 1.724 & 1 & 9 \\
$P \_$increase & 36 & 0.194 & 0.401 & 0 & 1 \\
$P \_$decrease & 36 & 0.306 & 0.467 & 0 & 1 \\
D_comp & 36 & 0.667 & 0.478 & 0 & 1 \\
\hline
\end{tabular}

Table 4 lists the difference on alliance performance (Longevity, $P$ increase, and $P$ _decrease) between high-degree complementary alliance and low-degree complementary alliance. For the whole sample and the strategic alliances started from 2005, there is no significant difference on alliance performance between high-degree complementary alliance and low-degree complementary alliance. For the strategic alliances started from 2006, there is significant difference on alliance performance, however, the sample of this group is very small. Overall, the results mean that high-degree complementary alliance and low-degree complementary 
alliance almost have the same alliance performance.

Table 4. Difference on alliance performance

\begin{tabular}{|c|c|c|c|c|c|}
\hline & & High-degree complementary & Low-degree complementary & Difference & T- statistics \\
\hline \multirow{3}{*}{ Total sample } & Longevity & $\begin{array}{l}5.125 \\
(24)\end{array}$ & $\begin{array}{l}4.75 \\
(12)\end{array}$ & 0.375 & 0.5644 \\
\hline & P_increase & $\begin{array}{l}0.25 \\
(24)\end{array}$ & $\begin{array}{l}0.083 \\
(12)\end{array}$ & 0.167 & 1.357 \\
\hline & $P \_$decrease & $\begin{array}{l}0.25 \\
(24) \\
\end{array}$ & $\begin{array}{l}0.417 \\
(12) \\
\end{array}$ & 0.167 & 0.958 \\
\hline \multirow{3}{*}{ Strategic alliances from 2005} & Longevity & $\begin{array}{l}5 \\
(9)\end{array}$ & $\begin{array}{l}4.6 \\
(5)\end{array}$ & 0.4 & 0.811 \\
\hline & $P$ _increase & $\begin{array}{l}0.222 \\
(9)\end{array}$ & $\begin{array}{l}0.2 \\
(5)\end{array}$ & 0.022 & 0.090 \\
\hline & $P \_$decrease & $\begin{array}{l}0.111 \\
(9) \\
\end{array}$ & $\begin{array}{l}0.2 \\
(5) \\
\end{array}$ & -0.089 & -0.389 \\
\hline \multirow{3}{*}{ Strategic alliances from 2006} & Longevity & $\begin{array}{l}4.286 \\
(7)\end{array}$ & $\begin{array}{l}5 \\
(2)\end{array}$ & $-0.714 * * *$ & -3.873 \\
\hline & P_increase & $\begin{array}{l}0.286 \\
(7)\end{array}$ & $\begin{array}{l}0 \\
(2)\end{array}$ & 0.286 & 1.550 \\
\hline & $P \_$decrease & $\begin{array}{l}0.286 \\
(7) \\
\end{array}$ & $\begin{array}{l}1 \\
(2) \\
\end{array}$ & $-0.714 * * *$ & -3.873 \\
\hline
\end{tabular}

Note. Observation is in parentheses. Asterisks $(* * *, * *$ and $*$ ) indicate statistical significance (at the $1 \%, 5 \%$, and $10 \%$ level respectively).

Table 5 lists the regression results. The coefficient of $D \_c o m p$ on Longevity and $P$ increase is positive but insignificant. The coefficient of $D_{-}$comp on $P_{-}$decrease is negative but insignificant. These results suggest that the degree of resource complementary do have positive impact on the alliance performance but insignificant.

Table 5. Regression results

\begin{tabular}{llll}
\hline & OLS regression & Probit regression & \\
\hline & Longevity & $P \_$increase & P_decrease \\
D_comp & 0.537 & 0.819 & -0.020 \\
& $(0.90)$ & $(1.20)$ & $(-0.04)$ \\
SOCB & -1.180 & 5.708 & 4.450 \\
& $(-0.81)$ & $(0.01)$ & $(0.01)$ \\
JOCB & -0.832 & 4.720 & 4.093 \\
& $(-0.61)$ & $(0.01)$ & $(0.01)$ \\
CCB & 1.074 & 5.038 & 3.847 \\
& $(0.88)$ & $(0.01)$ & $(0.01)$ \\
LIST & $2.144 * * *$ & -0.737 & 0.949 \\
cons & $(2.84)$ & $(-0.96)$ & $(1.29)$ \\
& $3.463 * *$ & -6.137 & -5.250 \\
$\mathrm{~N}$ & $(2.73)$ & $(-0.01)$ & $(-0.01)$ \\
adjusted R2 & 36 & 36 & 36 \\
pseudo R2 & 0.160 & & \\
\hline
\end{tabular}

Note. T-statistics are in parentheses. Asterisks $(* * *, * *$ and $*$ ) indicate statistical significance (at the $1 \%, 5 \%$, and $10 \%$ level respectively).

There are two potential reasons to explain the non-successful international strategic alliances in China's banking sector. First, foreign banks face the liability of foreignness in China's banking sector. Liability of foreignness is 
defined as "the costs of doing business abroad that result in a competitive disadvantage for an Multinational enterprises subunit... broadly defined as all additional costs a firm operating in a market overseas incurs that a local firm would not incur" (Zaheer, 1995, pp. 342-343). The additional costs include spatial cost (Zaheer \& Mosajiwsju, 1997), unfamiliar costs (Hennart, 1982; Buckley and Casson, 1976), host country environment costs (Zaheer \& Mosajiwsju, 1997), home country environment costs (Zaheer \& Mosajiwsju, 1997), etc. In China's banking sector, the regulation on foreign banks and Chinese banks are different before the end of 2006. In addition, foreign banks are not very familiar with Chinese banking market. Here is report from Wall Street Journal.

Holger Michaelis, a partner at Boston Consulting Group in Beijing, said a major letdown has been technical assistance, such as risk-control systems. Chinese bankers are often frustrated by foreign advisers who have rich international knowledge and experience but can't solve local problems because they don't understand local conditions. That is altering Chinese bankers' expectations that foreign advisers can offer immediate solutions, he said.

Second, interest conflict exists between Chinese banks and foreign financial institutions. There is another potential reason for the unsuccessful strategic alliance. The simultaneous existence of cooperation and competition between partners is an important characteristic of strategic alliances (Das \&Teng, 2000b). Cooperation and competition are opposing forces within strategic alliances, and the tension between simultaneous cooperation and competition may be responsible for the high failure rate of strategic alliances (Das \& Teng, 2000b). Liberalization policy that originated in China's enter in WTO potentially gives an incentive of divestments to foreign financial institutions. In the WTO accession agreement, China is required to open the banking market to foreign financial institutions on December 11, 2006 (Leigh \& Podpiera, 2006). It allows foreign financial institutions to establish incorporate banks in China, which can provide RMB denominated services to Chinese local customers without geographical restrictions (CBRC, "Report on the Opening-up of the Chinese Banking Sector," January 25, 2007). This fact suggests that foreign financial institutions can undertake and internalize cross-border activities through establishing their own banks in China. BOC announced an exclusive partnership with RBS PLC's private-banking arm in 2007. However, it finally started only its own proprietary wealth management business.

Based on the cooperation items about the credit card, the strategic alliances could be divided into two groups. One group is that foreign banks just provide technical assistance to Chinese banks. The other group is that foreign banks established joint venture center with Chinese banks. Table 5 (Figure 1) list the growth rate of the number of Chinese banks' credit card. From 2005 to 2008, the growth rate is very high, and it declines year by year. And the results indicate that there are no distinct differences between the two groups on the growth rate of credit card. The result is consistent with Table 4, which mean that the international strategic alliance in China's banking sector is not successful.

\section{A Case on CMB and Temasek}

Several anecdotal evidences also provide the support that the strategic alliances are not successful. The cooperation between CMB and Temasek starts from at 2004 and ends at 2006. The main cooperation is on the loans to Small and Medium Enterprises (SMEs) and a special team from Temasek lead by Wenyue Zhan is responsible for the cooperation. Based on the resource-based view, Figure 1 shows the resource framework of strategic alliance between CMB and Temasek. For CMB, it can supply Temasek the huge customer base and distribution network and need the large capital to replenish the capital adequacy ratio and advanced knowledge and experience. Temasek could supply CMB large capital and experience on SMEs finance and want to get high investment return not only through stock price premium but also through an independent division on SMEs finance. From the resource supply and resource demand of both sides, the strategic alliance is in the resource complementary. 


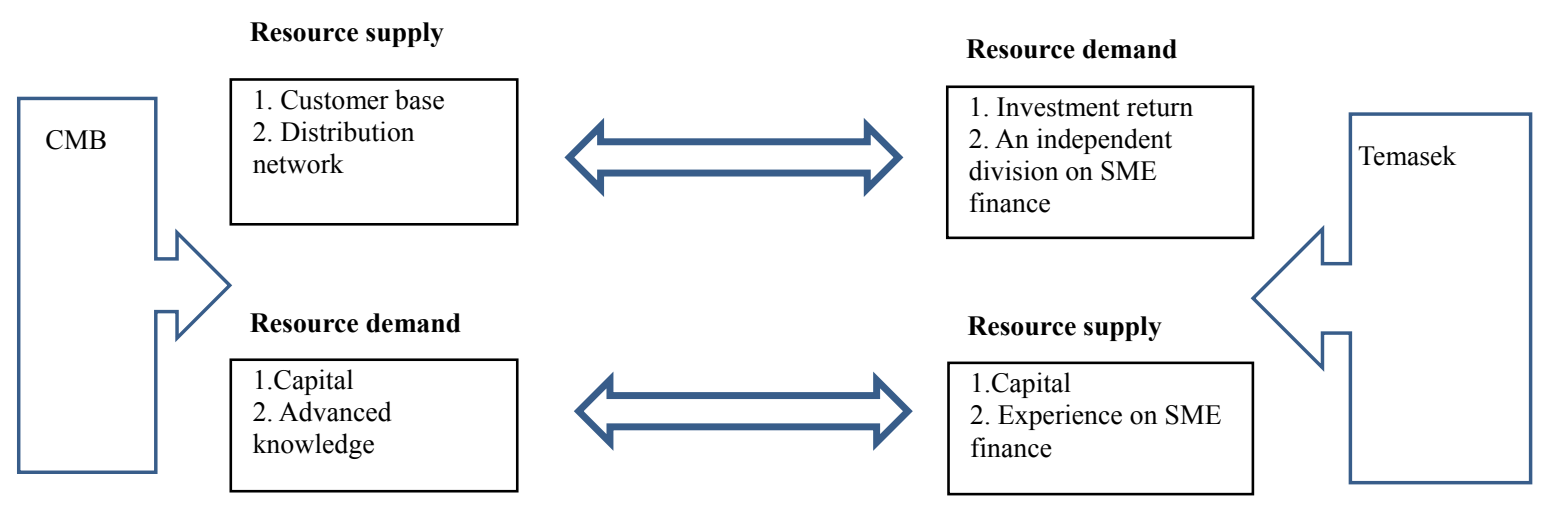

Figure 1. Resource framework of strategic alliance between CMB and Temasek

However, the cooperation is not successful. From January 2006, the team went into CMB, one year later, Temasek built the whole business process, and gradually built an independent division which is similar like an independent credit card center. However, some core management and operation haven't built'. Until Temasek cut their whole equity stakes, this division hasn't yet been operating a business in accordance with the Temasek model on loans to SMEs. And from 2008, Temasek cooperates with Bank of China and China Construction Bank on SMEs finance.

In sum, although the resource alignment between CMB and Temasek is complementary, the alliance performance is not successful. The failure of reasons: first, the communication among CMB and Temasek is not well. It implies the existence of liability of foreignness in the strategic alliances between CMB and Temasek. Second, interest conflict exists among CMB and Temasek, which is consistent with the second reason of the section 4. And these potential two reasons are consistent with the results in section 5.

\section{Conclusions}

This paper uses resource-based view to examine whether different resource complementary degree contributes to different international strategic alliance performance in China's banking sector. Through OLS regression and probit regression analyses, this paper found that resource complementary has positive impact on alliance performance but not significant which suggest that the international strategic alliances in China's banking sector don't contribute to a good alliance performance. Two potential reasons could explain the results. First, the existence of liability of foreignness leads to the mismatch resources between Chinese banks and foreign banks. Second, the potential competition between foreign banks and Chinese banks hinder foreign banks to contribute their 100 percent resources. In addition, the case study on strategic alliance between CMB and Temasek also shows that high resource complementary doesn't contribute to high alliance performance.

\section{Acknowledgments}

HERE, I delete one sentence.This paper has been financially supported by National Natural Science Foundation of China (Project NO.: 71363016, 71263016, and 71303097), Jiangxi Province Social Science Twelve Five Project (Project NO.: 13YJ09), Jiangxi Postdoctoral Science Foundation (Grant No.: 2014KY57), and China Postdoctoral Science Foundation (Grant No.: 2014M551850).

\section{References}

Barney, J. B. (1991). Firm resources and sustained competitive advantage. Journal of Management, 17(1), 99-120. http://dx.doi.org/10.1177/014920639101700108

Beamish, P. W. (1987). Joint ventures in LDCs: Partner selection and performance. Management International Review, 27(1), 23-37.

Bucklin, L. P., \& Sengupta, S. (1993). Organizing successful co-marketing alliances. Journal of marketing, 57, 32-46. http://dx.doi.org/10.2307/1252025

Chung, S. A., Singh, H., \& Lee, K. (2000). Complementarity, status similarity and social capital as drivers of alliance formation. Strategic Management Journal, $21(1), \quad 1-22$. http://dx.doi.org/10.1002/(SICI)1097-0266(200001)21:1<1::AID-SMJ63>3.0.CO;2-P

Das, T. K., \& Teng, B. S. (1997). Sustaining strategic alliances: Options and guidelines. Journal of General Management, 22, 49-64. 
Das, T. K., \& Teng, B. S. (2000a). A resource-based theory of strategic alliances. Journal of Management, 26(1), 31. http://dx.doi.org/10.1016/S0149-2063(99)00037-9

Das, T. K., \& Teng, B. S. (2000b). Instabilities of strategic alliances: An internal tensions perspective. Organization Science, 11, 77-101. http://dx.doi.org/10.1287/orsc.11.1.77.12570

Dollinger, M. J., \& Golden, P. A. (1992). Interorganizational and collective strategies in small firms: Environmental effects and performance. Journal of Management, 18(4), 695-715. http://dx.doi.org/10.1177/014920639201800406

Eisenhardt, K. M., \& Schoonhoven, C. B. (1996). Resource-based view of strategic alliance formation: Strategic and social effects in entrepreneurial firms. Organization Science, 7(2), 136-150. http://dx.doi.org/10.1287/orsc.7.2.136

García-Herrero, A., \& Santabárbara, D. (2008). Does the Chinese banking system benefit from foreign investors. BOFIT Discussion Papers, 11.

Hamel, G., Doz, Y. L., \& Prahalad, C. K. (1989). Collaborate with your competitors and win. Harvard Business Review, 67(1), 137-139.

Hill, R. C., \& Hellriegel, D. (1994). Critical contingencies in joint venture management: Some lessons from managers. Organization Science, 5(4), 594-607. http://dx.doi.org/10.1287/orsc.5.4.594

Lei, D. (1993). Offensive and defensive uses of alliances. Long Range Planning, 26(4), 32-41. http://dx.doi.org/10.1016/0024-6301(93)90055-K

Kogut, B. (1989). The stability of joint ventures: Reciprocity and competitive rivalry. Journal of Industrial Economics, 38(2), 183-198. http://dx.doi.org/10.2307/2098529

Olk, P. (1997). The effect of partner differences on the performance of R\&D consortia. In P. W. Beamish \& K. J. P. (Eds.), Cooperative Strategies: North American Perspectives (pp. 133-159). San Francisco: New Lexington Press.

Park, S. H., \& Russo, M. V. (1996). When competition eclipses cooperation: An event history analysis of joint venture failure. Management Science, 42(6), 875-890. http://dx.doi.org/10.1287/mnsc.42.6.875

Parkhe, A. (1993). Strategic alliance structuring: A game theoretic and transaction cost examination of inter firm cooperation. The Academy of Management Journal, 36(4), 794-829. http://dx.doi.org/10.2307/256759

Reuer, J. J., \& Miller, K. D. (1997). Agency costs and the performance implications of international joint venture internalization. Strategic Management Journal, 18(6), 425-438. http://dx.doi.org/10.1002/(SICI)1097-0266(199706)18:6<425::AID-SMJ878>3.0.CO;2-\#

Rothaermel, F. T., \& Deeds, D. L. (2004). Exploration and exploitation alliances in biotechnology: A system of new product development. Strategic Management Journal, 25(3), 201-221. http://dx.doi.org/10.1002/smj.376

Steensma, H. K., \& Corley, K. G. (2000). On the performance of technology-sourcing partnerships: the interaction between partner interdependence and technology attributes. The Academy of Management Journal, 43(6), 1045-1067. http://dx.doi.org/10.2307/1556334

Teece, D. J. (1986). Profiting from technological innovation: Implications for integration, collaboration, licensing and public policy. Research Policy, 15(6), 285-305. http://dx.doi.org/10.1016/0048-7333(86)90027-2

Thomas, J. B., \& Trevino, L. K. (1993). Information processing in strategic alliance building: A multiple case $\begin{array}{lllll}\text { approach. Journal of } & \text { Management }\end{array}$ http://dx.doi.org/10.1111/j.1467-6486.1993.tb00326.x

Williamson, O. E. (1975). Markets and hierarchies: Analysis and antitrust implications. New York: Free Press.

Zaheer, S. (1995). Overcoming the liability of foreignness. Academy of Management Journal, 38, 341-363. http://dx.doi.org/10.2307/256683

Zhu, Y., Zeng, Y., Li, P., \& He, J. (2008). Chinese banks attract overseas strategic investors: Background, arguments and comments. Management World, (1), 22-37. 


\section{Notes}

Note 1. Transaction cost economics advances the notion of opportunism, or pursuing self-interest with guile (Williamson, 1975). To deter opportunistic behavior, alliance partners need to employ various coordination mechanisms involving "high outlays for drafting, negotiating, monitoring, and enforcing contingent claims contracts, i.e., outlays collectively referred to as transaction costs" (Parkhe, 1993: 803). High transaction costs of alliances are responsible for poor alliance performance and alliance instability (Park \& Russo, 1996).

Note 2. In China's banking sector, foreign banks' strategic investment in Chinese banks is allowed from 2001 and encouraged from August 2003. Because foreign banks could acquire some equity stake of Chinese banks, and they also have to provide some technical assistance and business cooperation, e.g. cooperation on credit card and private banking. Therefore, these foreign strategic investments can be viewed as strategic alliances.

Note 3. Doz (1988), for instance, observes that the complementarily of strengths and assets between firms is of the clear even prior to negotiations on the terms of alliances because it is what brings the partners together in the first place.

Note 4. For example, differential government treatment of domestic vs. foreign firms, nationalistic buyers' reluctance to buy from foreign firms.

Note 5. For example, regulatory restrictions imposed by a firm's home government.

Note 6. The Wall Street Journal website: Jason L. \& Dan F., As foreigners pull up stakes, China reassesses banks' path, January 8, 2009, http://online.wsj.com/article/SB123135303986861431.html?mod=rss_whats_news_us\&utm_source=feedburner \&utm_medium $=$ feed\&utm_campaign $=$ Feed $\% 3 \mathrm{~A}+\mathrm{wsj} \% 2 \mathrm{Fxml} \% 2 \mathrm{Frss} \% 2 \mathrm{~F} 3-7011+\% 28 \mathrm{WSJ} . \mathrm{com} \% 3 \mathrm{~A}+\mathrm{What} \% 2$ $7 \mathrm{~s}+\mathrm{News}+\mathrm{US} \% 29$

Note 7. The Wall Street Journal website: Jason L. \& Dan F., As foreigners pull up stakes, China reassesses banks' path, January $\quad 8, \quad 2009$, http://online.wsj.com/article/SB123135303986861431.html?mod=rss_whats_news_us\&utm_source=feedburner \&utm_medium $=$ feed\&utm_campaign $=F$ Feed $\% 3 \mathrm{~A}+\mathrm{wsj} \% 2 \mathrm{Fxml} \% 2 \mathrm{Frss} \% 2 \mathrm{~F} 3 \_7011+\% 28 \mathrm{WSJ} . \mathrm{com} \% 3 \mathrm{~A}+\mathrm{What} \% 2$ $7 \mathrm{~s}+\mathrm{News}+\mathrm{US} \% 29$

Note 8. Although Temasek is a Singapore government holding company, the business of SMEs in Southeast Asia Credit has brilliant performance, and it has successful experience on pricing, technology, rating model.

Note 9. People website: http://finance.people.com.cn/GB/1040/59940/70861/5385341.html

\section{Copyrights}

Copyright for this article is retained by the author(s), with first publication rights granted to the journal.

This is an open-access article distributed under the terms and conditions of the Creative Commons Attribution license (http://creativecommons.org/licenses/by/3.0/). 